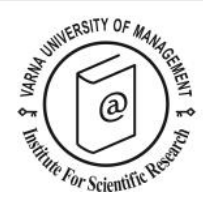

\title{
The impact of Serbian tourists' risk perception on their travel intentions during the COVID-19 pandemic
}

\author{
Goran Perić ${ }^{1 *}$ Sandra Dramićanin ${ }^{2}$ and Momčilo Conić3
}

\begin{abstract}
${ }^{1}$ Academy of Professional Studies South Serbia, Department of Business Studies Blace, Kralja Petra I Street, No. 1, 18420 Blace, Serbia, E-mail: goran.peric@vpskp.edu.rs

${ }^{2}$ University of Kragujevac, Faculty of Hotel Management and Tourism in Vrnjačka Banja, Vojvođanska Street bb, Vrnjačka Banja, Serbia, E-mail: sandradramicanin@hotmail.com

3 Academy of Professional Studies South Serbia, Department of Business Studies Leskovac, Vlade Jovanovića Street, No. 8, 16000 Leskovac, Serbia, E-mail: conic.momcilo@vpsle.edu.rs

* Corresponding author
\end{abstract}

\begin{abstract}
The purpose of this study is to examine the impact of Serbian tourists' risk perception on their intentions to travel during the COVID-19 pandemic with the control of socio-demographic characteristics. This research was conducted in the period from 18 May until 24 May 2020, on a sample of 348 respondents, through an online questionnaire. The principal component analysis identified five categories of the perceived risk affecting travel intentions during the COVID-19 pandemic: the health risk, the psychological risk, the financial risk, the destination risk and the travel risk. Logistic regression was used to examine the way in which risk perception affects the intentions and destinations of travel during the COVID-19 pandemic. The research findings indicate that the risk perception (health, psychological, financial and destination risks) among Serbian tourists negatively affects their travel intentions during the COVID-19 pandemic. In terms of travel destinations, the results indicate that the travel risk negatively affects travel abroad, while the health risk, being on the verge of significance, proved to be a predictor of travel abroad during the COVID-19 pandemic. Furthermore, the variable of monthly income of the respondents was singled out as a significant predictor of travel abroad during the pandemic. Finally, the implications, limitations and recommendations for future research are presented in the paper.
\end{abstract}

Keywords: COVID-19, risk perception, travel intentions, Serbia

Citation: Perić, G., Dramićanin, S. \& Conić, M. (2021). The impact of Serbian tourists' risk perception on their travel intentions during the COVID-19 pandemic. European Journal of Tourism Research 27, 2705. 


\section{Introduction}

Various types of crises during the $2 \mathbf{1}^{\text {st }}$ century, such as terrorism, natural disasters, the danger of pandemics, increase in oil prices, exchange rate fluctuations, political and economic uncertainties, represent risky events faced by the world tourism. The tourism industry, especially the international tourism demand, is very defenceless to crises or disasters, as it imposes a risk to health and personal safety for potential tourists (Estevão \& Costa, 2020; Cró \& Martins, 2017).

In order for tourism to develop, without any risks to the safety of trip participants, open borders, stable political, social and economic, as well as health and safety conditions are necessary. The disturbance of stability globally at the beginning of March 2020 led to the complete extinction of tourist movements and the entire tourist activity (Gössling et al., 2020). Today, the world is in the state of unprecedented change, where international trade, production and global energy structures, along with the global financial system, are subject to deep adaptation and rapid change caused by the COVID-19 pandemic (Ma et al., 2020). The new corona virus (COVID-19) was first identified in 2019 in the city of Wuhan, China (Gössling et al., 2020). The disease has been spreading worldwide since 2019, leading to the COVID-19 virus pandemic. According to the data (as of 23 October 2020), there are currently 42,117,097 COVID-19 cases in the world, 1,144,442 of which died (World Health Organization, 2020). The pandemic has led to global social and economic disturbances in the world (Sumner et al., 2020).

COVID-19 has changed the world irretrievably in every imaginable respect and it has had a heavy impact on the international travel, tourism demand, and the hospitality industry, which is one of the world's largest employers and which is highly sensitive to significant shocks like the COVID-19 pandemic (Chang et al., 2020). The nature of the tourism industry is such that the consequences of the impact of the COVID-19 pandemic are visible in all domains of tourism (Chinazzi et al., 2020). The global domain of the virus and the control of the disease in the form of quarantine, reduced mobility, and isolation have had a dramatic impact on the domestic and international tourism: transportation, travel agencies and tour operators, hospitality, business, and event tourism (Hoque et al., 2020). International travel and business operations have been disrupted and the tourism and travel industry as a whole have been put on hold, suffering significant losses. The COVID-19 pandemic is estimated to have caused a $37 \%$ drop from the global growth forecast for 2020 (World Tourism Cities Federation (WTCF) and Tourism Research Center, 2020). Global concerns regarding the COVID-19 pandemic, travel problems and other circumstances prevent the normal growth and development of tourism. The World Travel \& Tourism Council (WTTC) warns that the COVID-19 pandemic will reduce employment by 50 million people worldwide in the travel and tourism industry, and Asia is expected to be affected the most (World Economic Forum, 2020). The World Tourism Organization shows that in 2020, there will be a reduction in total international arrivals by 20 to 30 percent compared to 2019, which would cause a drop in revenue of 300-450 billion dollars globally (World Tourism Organization, 2020).

According to Matiza (2020), the global tourism industry is facing multiple challenges, both in tourism demand (the perceived health, social and psychological risk) and in tourism supply (large fiscal deficit, job loss, company liquidation). Countries across the world are implementing a wide range of measures to mitigate the impact of the COVID-19 pandemic and to encourage the recovery of the tourism and travel sectors. It is of vital importance to study the COVID-19-induced tourism crisis (Chen et al., 2020a), as well as to research the attitudes and perceptions of consumers, in order to understand the changes and characteristics of the tourism demand (Ivanova et al., 2020).

The revival of tourist movements within Serbia will undoubtedly be accompanied by a significant dose of anxiety and caution in terms of the various risks of travel among trip participants. On the other hand, 
restrictive measures and rigorous procedures for accepting foreign tourists will remain in force for the longest time, and travel from Serbia to countries strongly affected by the pandemic, such as Spain, France and Italy, which are among the leading receptive countries, is risky and far more difficult. The tourism sector in Serbia is suffering huge losses due to the COVID-19 pandemic. According to the data of the Statistical Office of the Republic of Serbia (2020), the number of arrivals for the period from January to August 2020 for domestic tourists is lower by $26 \%$, and the number of arrivals of foreign tourists is lower by $73.5 \%$ compared to the same period in 2019. Due to the COVID-19 pandemic and restricted movement, Serbian tourists are expected to travel and spend their free time mostly in Serbia, but the reasons for that are better security and reduced risk when traveling within the borders of their own country (if an unexpected situation occurs again, it is possible to return home easier and faster than if tourists face such situations while traveling abroad). It is completely understandable that tourists feel safer when they travel in their country or when they travel to destinations not far from their place of residence (Ivanova et al., 2020).

Modern tourism has turned into a global phenomenon, which is faced with the problem of safety and protection of tourists. These are various dangers and risky situations, both during travel and during the stay of tourists in destinations. In addition to affecting the natural and anthropogenic attractiveness of a destination, different types of risks hinder tourist flows and have an impact on the tourist perception about the destination and they inevitably affect the intention to travel. The COVID-19 virus pandemic, with its devastating effects, confirms this. Predictions show that the recovery of the tourism industry and travel will be extremely gradual and difficult (Nepal, 2020).

Health crises have shown a certain frequency in recent years. The biggest problems created by these crises are related to human health and food safety (Milićević \& Ervaćanin, 2016). Pandemics are frequent and they can negatively affect tourists' perception of a travel destination. Accordingly, a lot of questions arise about the readiness of regional and global tourism-related institutions to coordinate crisis management and recovery actions (Jamal \& Budke, 2020). Health crises and their impact on the domestic and international tourism have been the focus of researchers from various scientific fields (Abukhalifeh et al, 2018; Cahyanto et al., 2016; Mair et al., 2016; Burkle, 2006; Cooper, 2005). Numerous studies investigated the impact of the COVID-19 pandemic on the tourism industry (Brouder et al., 2020; Gössling et al., 2020; Zenker \& Kock, 2020; Jamal \& Budke, 2020; Yang et al., 2020; Chang et al., 2020). Previous research has dealt with the risk perception and the intention to avoid or cancel travel during and after the COVID-19 pandemic (Ivanova et al., 2020; Wachyuni \& Kusumaningrum, 2020; Neuburger \& Egger, 2020; Kourgiantakis et al., 2020; Bae \& Chang, 2020), but research has not identified how this pandemic, which transcends all previous health and tourism crises, affects the risk perception of travel and the intentions during a pandemic. In line with the above, the purpose of this study is to examine the impact of risk perception among Serbian tourists on their travel intentions during the COVID-19 pandemic. In particular, the objectives of this study are (1) to identify factors influencing risk perception on travel intentions during the COVID-19 virus pandemic; and (2) to examine the impact of risk perception among Serbian tourists on the intentions and travel destination during the COVID-19 pandemic with the control of socio-demographic characteristics.

\section{Literature review}

Risk perception in tourism

Risk is defined as exposure to certain threats or dangers (Macquarie, 1999, as cited in Reisinger \& Mavondo, 2005) or potential loss of something valuable (Priest, 1990, as cited in Reisinger \& Mavondo, 2005). Three types of risk are mentioned in literature: objective, actual, and perceived risk (Seabra et al., 2013). Bauer (2000) was among the first to present the view that consumer behavior is conditioned 
by risk, bearing in mind that each individual action of consumption is associated with uncertainty, which can lead to unforeseen and unpleasant consequences. Researchers are mainly focused on the study of perceived risk, because it determines behavior (Bauer, 200o). Perceived risk is assessed by consumers in a particular context (Haddock, 1993) and it refers to consumers' perceptions of the overall negative aspect of a product/service purchase based on an assessment of possible negative outcomes and the likelihood that those outcomes will occur (Mowen \& Minor 1998, as cited in Cahaner et al., 2015). In other words, the perceived risk represents the possibility that a product/service will not offer the expected benefits (Roselius, 1971).

The research of perceived risk in tourism occupies an important place, as evidenced by numerous studies (Chen et al., 202ob; Hwang \& Choe, 2020; Le \& Arcodia, 2018; Deng \& Ritchie, 2018; Seabra et al., 2013; Cahaner et al., 2015; Floyd et al., 2004; Fuchs \& Reichel, 2006; Reisinger \& Mavondo, 2005; Mattila, 2001; Sönmez \& Graefe, 1998a; Tsaur et al., 1997; Roehl \& Fesenmaier, 1992). Risk in tourism refers to the tourists' perception about possible negative consequences during their stay in a tourist destination (Tsaur et al., 1997), having in mind the specific characteristics of the tourist product, and the fact that tourists can be exposed to a large number of possible risks, uncertainties in the decisionmaking process (Fuchs \& Reichel, 2006). In addition, it should be noted that risk perception is a very subjective and individual issue in the mental structure of each individual (Yang \& Nair, 2014), and that risk perception in tourism varies depending on the characteristics of tourists and the type of risks perceived (Reisinger \& Mavondo, 2006). The perceived risk also consists of the perceived susceptibility to a particular disease, i.e. the severity of the disease (Floyd et al., 200o). Individuals who consider themselves to be at risk for the disease will take certain measures to prevent the risk, which may be to cancel and avoid travel (Neuburger \& Egger, 2020; Brewer et al., 2007). The perception of individuals' risk of traveling during a particular health crisis or pandemic depends not only on the possibility of infection, but also on media reporting and information through social networks (Yu et al., 2020; McKercher \& Chon, 2004).

\section{Types of travel risk perceptions}

Risk perception in tourism is associated with a number of factors (Seabra et al., 2013). The first study on risk perception identified five dimensions of risk (Jacoby \& Kaplan, 1972): the psychological risk (how purchasing can affect what we think about ourselves), the social risk (how purchasing can affect what others think about us), the financial risk (the amount of costs compared to income and the perception of value for the money spent), the time risk (planning, execution and opportunity time costs) and the physical risk (how purchasing can affect our physical and mental well-being). The five listed risk dimensions were adopted by the first studies dealing with risk perception in tourism (Stone \& Grønhaug, 1993; Roehl \& Fesenmaier, 1992; Cheron \& Ritchie, 1982). Roehl and Fesenmaier (1992) used seven dimensions of risk in their study and identified three new dimensions of perceived risk: physical and equipment risk, vacation risk, and destination risk. Subsequent research has identified additional risk dimensions including satisfaction risk, i.e. the anticipation that travel will not ensure personal satisfaction (Cheron \& Ritchie, 1982), the political risk (political instability and unrest) (Seddighi et al., 2001; Sönmez \& Graefe, 1998a), the health risk (Richter, 2003; Sönmez \& Graefe, 1998b), the risk of terrorism (Sönmez \& Graefe, 1998b), and the risk of crime (Pennington-Gray \& Schroeder, 2013). This wide range of perceptions of possible risks is the greatest challenge in tourism, as it can be assumed that different circumstances when traveling can lead to different perceptions of risks that may deter tourists from traveling, at the same time bearing in mind the fact that tourists belong to different social and cultural groups, as well as that there are various market segments (Kozak et al., 2007; Quintal et al., 2010). Within this study, due to the nature of the research itself, a brief overview of health risk will be outlined. 
Despite the enormous advances in medicine, modern tourists are still exposed to health risks, which are an integral part of the nature of travel (Jonas et al., 2010). The health risk can, according to Wilks et al. (2006), be interpreted as one of the factors that can endanger the safety and security of passengers. The World Health Organization (2012) links this type of risk to international travel and emphasizes that the level of risk varies depending on the purpose of travel, characteristics of passengers, their behavior, standards of accommodation, hygiene and sanitation, and conditions prevailing in the destination. Accordingly, health risks that may exist during travel and stay at a destination may shape the risk perception in tourists, which may result in an impact on behavior and destination choice (Jonas et al., 2010). This is primarily important for both the tourists and the tourism service providers. Research on the impact of health risk on the destination choice and travel behavior is quite uneven in terms of the perception of health risk by tourists. The results of a study conducted by Cossens and Gin (1995) indicate that, although tourists are aware of health risks, most did not intend to change their chosen destination, while another research suggests that, when it comes to health risks, tourists' perceptions of potentially dangerous destinations are even broader, and more comprehensive than their perception of other risks (Jonas et al., 2010). Thus, a certain number of tourists perceive travel to Africa and Asia as health risks due to the infectious diseases, as well as poor water or food quality, while travel to Europe and North America is perceived as safe (MacLaurin, 2004; Carter, 1998; Cossens \& Gin, 1995). However, in the last two decades, viral infections and epidemics have become more and more present in the world, crossing the borders of the countries where they originated and they are not characteristic only of continents such as Asia and Africa. For example, epidemics such as the foot-and-mouth disease, SARS, H1N1 and $\mathrm{H}_{5} \mathrm{~N}_{1}$ have had a huge impact on the tourism industry (Lee et al., 2012; Jonas et al., 2010; Kuo et al., 2009; $\mathrm{Au}$ et al., 2005). Understanding this problematic link between tourism and health is important, as organisations and individuals strive to make global tourism more sustainable (Grout, 2015).

Previous studies indicate that the perception of risk in tourism is also influenced by personal factors, such as tourist function or type (Lepp \& Gibson, 2003), previous experience on trips (Lepp \& Gibson, 2003; Sönmez \& Graefe, 1998a, 1998b), information retrieval and information sources (Kozak et al., 2007; Pizam et al., 2004; Sönmez \& Graefe, 1998a), personality type (Lepp \& Gibson, 2008; Reisinger \& Mavondo, 2005; Pizam et al., 2004), culture and nationality (Kozak et al., 2007; Reisinger \& Mavondo, 2006; Pizam et al., 2004; Seddighi et al., 2001), then demographic characteristics, such as gender (Pizam et al., 2004; Lepp \& Gibson, 2003), age (Lepp \& Gibson, 2003; Gibson \& Yiannakis, 2002), income and education levels (Floyd \& Pennington-Gray, 2004; Mitchell \& Vassos, 1998; Sönmez \& Graefe, 1998b).

\section{Risk perceptions and travel intentions}

Protection Motivation Theory was used to explain the travel intention and its association with the perceived risk (Rogres, 1975 as cited in Qi et al., 2009). This theory represents an adaptation of the theory of expected value and it focuses on risk perception and "cognitive assessment processes" that influence changes in intentions or attitudes (Qi et al., 2009). The travel intention is the tendency of persons to analyse their future tourist behavior, also the tourist enthusiasm to participate in certain tourist activities (Kozak, 2001; Zeithaml et al., 1996).

The perceived risk and safety greatly impact the travel intention (Henthorne et al., 2013; Reisinger \& Mavondo, 2005) and, accordingly, tourists have several options, i.e. they can continue their travel plans, change their destination, and change their plans for travel or obtain relevant information if they choose to pursue their travel plans (Seabra et al., 2014; Kozak et al., 2007; Reisinger \& Mavondo, 2005). However, tourists typically choose low-risk destinations and avoid destinations that have a high level of safety risk (Uriely et al., 2007; Brin, 2006; McKercher \& Hui, 2004). Thus, destinations that are perceived as risky may become undesirable (Crompton, 1992) and be eliminated from the selection process (Sönmez \& 
Graefe, 1998b). Accordingly, the perceived risk does not affect only the tourist decision to choose a destination, but also whether to travel or not (Rittichainuwat \& Chakraborty, 2009; Reisinger \& Mavondo, 2005; Lepp \& Gibson, 2003; Sönmez \& Graefe, 1998b), as well as the intention to return to the destination again (Schusterschitz et al., 2010). Qi et al. (2009) examined the perceived risk in American students in relation to the host country of the Olympic Games (China), i.e. how the perceived risks are related to their travel intentions, and the research findings indicated that students perceived that the host country of the Olympic Games, i.e. China represented a moderately risky destination and they regarded attending the Beijing Olympics less risky than any other individual or organized tourist trip to China. The relationship between the perceived risk and the travel intention was explored in the study by Floyd et al. (2004). They examined the impact of the perceived risk on the travel intentions after the terrorist attack of September $11^{\text {th }}$ 2001, and the results of the research showed that the travel intentions in the next 12 months (relative to the time of the research) were related to safety issues, perceived social risk, previous experiences and income (Floyd et al., 2004). Recent research conducted in Germany, Austria and Switzerland indicates that the intention to travel during a COVID-19 pandemic is largely related to the perception of travel risks in general, especially in destinations where the epidemic is powerful, as well as the increased health risk of COVID-19 infection (Neuburger \& Egger, 2020). Bae and Chang (2020) examined the impact of the perceived risk on the behavioral intentions toward "untact" tourism during the COVID-19 pandemic, and the results indicate that the perceived risk significantly influences behavioral intentions even with a positive attitude toward untact tourism. Research conducted on Crete (the Greek island) indicated that the COVID-19 pandemic negatively affects travel intentions, i.e. the results confirmed that the pandemic generated worry and insecurity in several aspects of tourists' daily lives (Kourgiantakis et al., 2020). Ivanova et al. (2020) investigated the intentions of traveling in the COVID-19 post-pandemic world, and the findings of the research indicate that Bulgarian tourists are ready to connect the tourist trends, i.e. to travel within two months after travel is allowed, and they will travel in the country, and the trip will depend on the overall perception of personal safety of tourists.

\section{Methodology}

Measures and questionnaire development

The questionnaire used for this survey was divided into four categories: the description of the survey, questions related to travel intentions, statements measuring the perceived risk, and questions about demographic characteristics.

The intention of traveling during the COVID-19 virus pandemic was measured as a general measure (Floyd et al., 2004), and the responses were coded (o-No and 1-Yes), while subjects who intended to travel responded to another question, concerning the destination of the trip, and their answers were coded (o-In the country and 1-Abroad).

The constructed instrument measure perceived risk based on the statements of the scales used in the relevant studies (Deng \& Ritchie, 2018; Jonas et al., 2010; Fuchs \& Reichel, 2006; Wen et al., 2005; Floyd et al., 2004). Respondents assessed the degree to which they agree with the given statements using a five-point Likert scale ( $1=$ strongly disagree to $5=$ strongly agree). The statements are coded so that a higher number indicates a higher risk perception. Finally, respondents declared their gender, age, education, and their monthly income.

Prior to the study, 15 semi-structured interviews were conducted with respondents of different age groups who intended to travel during the COVID-19 virus pandemic, in order to confirm the statements for measuring the perceived risk identified in the literature review (Deng \& Ritchie, 2018; Jonas et al., 
2010; Fuchs \& Reichel, 2006; Wen et al., 2005; Floyd et al., 2004), as well as the statements defined by researchers. Respondents fully agreed with the defined statements. After that, a pilot study was conducted on a sample of 50 subjects and the reliability of the scale for measuring the perceived risk was examined, where the obtained result indicated adequate reliability and consistency of statements (Cronbach $\alpha=0.87$ ).

\section{Data collection and sample characteristics}

The collection of primary data was performed using the questionnaire technique, including the method of research which systematically collects data from a set of respondents in the form of personal views. The research was conducted in the period from 18-24 May 2020, through an online questionnaire, which was distributed via the social networks Facebook and Twitter, using the non-probability sampling method, i.e. the convenience sample. The respondents were informed that participation in the research was anonymous and voluntary, and that the results would be used exclusively for scientific research purposes. Table 1 shows the sample characteristics.

Table 1. Sample characteristics

\begin{tabular}{|c|c|c|}
\hline & \multicolumn{2}{|c|}{ Frequency $(N=348)$} \\
\hline & $N$ & $\%$ \\
\hline \multicolumn{3}{|l|}{ Intention to travel } \\
\hline Yes & 265 & 76.1 \\
\hline No & 83 & 23.9 \\
\hline \multicolumn{3}{|l|}{ Destination } \\
\hline In the country & 150 & 56.6 \\
\hline Abroad & 115 & 43.4 \\
\hline \multicolumn{3}{|l|}{ Gender } \\
\hline Male & 242 & $69 \cdot 5$ \\
\hline Female & 106 & 30.5 \\
\hline \multicolumn{3}{|l|}{ Education } \\
\hline High school & 61 & $17 \cdot 5$ \\
\hline College & 60 & 17.2 \\
\hline University & 138 & $39 \cdot 7$ \\
\hline Master/PhD & 89 & 25.6 \\
\hline \multicolumn{3}{|l|}{ Monthly income } \\
\hline To 29.000 RSD & 57 & 16.4 \\
\hline From 30.000 to 60.000 RSD & 128 & 36.8 \\
\hline From 61.000 to 90.000 RSD & 113 & 32.5 \\
\hline Over 91.0oo RSD & 50 & 14.4 \\
\hline
\end{tabular}

Note: Excange rate: 1 euro=117.58 RSD

The sample on which the analysis was performed consisted of 348 respondents, without missing data. The majority of respondents, 265 (76.1\%) intend on travelling during the COVID-19 virus pandemic; 150 (56.6\%) will travel in the country; women represent a greater share $(69.5 \%)$; the respondents are on average middle-aged $(\mathrm{M}=39.87$; $\mathrm{SD}=10.86) ; 65.2 \%$ of the respondents have higher education (university degree, master's or PhD degree); the largest number of respondents (36.8\%) have incomes between 30,000 RSD and 6o,00o RSD. 
Principal components analysis

To identify the factors influencing the risk perception of travel intentions during the COVID-19 virus pandemic, principal components analysis (PCA) with verimax rotation was arranged. The goal of PCA was to identify latent variables. Data adequacy verification for PCA was performed. A sample size of 348 respondents was sufficient for PCA (Pearson \& Mundform, 2010). The correlation between the variables was checked by means of a correlation coefficient matrix by calculating the Kaiser-Meyer-Olkin (KMO) adequacy measure and the Bartlett's sphericity test (Tabachnick \& Fidell, 2019). The KMO measure of sample adequacy is 0.888 , which is significantly above the recommended value of 0.6 and Bartlett's sphericity test shows that it is significant $\left(\chi_{2}(253)=4549.74 ; \mathrm{p}=0.00\right)$, which indicates that the data is adequate for PCA, i.e. that there is a significant correlation between variables. There are many coefficients in the correlation coefficient matrix that are greater than 0.3 , which also indicates the adequacy of the data for PCA.

\section{Logistic regression}

Logistic regression was used to check the impact of risk perception on the intention and destination of travel during the COVID-19 virus pandemic, with the control of socio-demographic characteristics. Independent variables are risk factors singled out by the PCA. Factors were calculated as average answers (the sum of answers to the questions affected by the factor is divided by the number of questions). Socio-demographic variables in the model are gender, age, education, and monthly income. Gender is a dichotomous variable, while age is a continuous variable expressed in years. Education and monthly income are categorical variables defined in four categories (described in sample characteristics). Preliminary analysis verified the assumptions, the presence of extreme values and multicollinearity. No violation of the assumptions for the use of logistic regression was observed.

\section{Results and discussion}

PCA was performed on a risk perception scale with 23 statements and the results suggest a 5-factor solution that explains $68.18 \%$ of the variance. All factors eigenvalue is greater than 1 and loading greater than 0.50 were retained. The reliability of the identified factors is very good, i.e. the reliability coefficient is $\alpha>0.80$, except for one factor where the reliability coefficient is $\alpha=0.76$, whereas the composite reliability for all factors above the recommended 0.70 . This indicates that all constructs have good internal reliability and consistency. PCA findings after rotation produced a clear factor structure with relatively high loading and minimal overlap between items, indicating factor independence. Factors identified by PCA were designated as: health risk, psychological risk, financial risk, destination risk, and travel risk (Table 2).

The first factor, health risk, explains $16.74 \%$ of the variance and it has a high reliability coefficient $(\alpha=0.86 ; C R=0.84)$. This risk is related to health safety, hygiene in accommodation facilities, the health system of the destination and travel health insurance. The second factor, psychological risk, contains six statements and explains almost the same percentage of variance (16.69\%), and its reliability coefficient is $\alpha=0.87 ; C R=0.73$. Statements within this factor, i.e. risk, refer to the prevention measures, care not to worsen the epidemiological situation in the destination during the trip, fear of the COVID19 virus, appearance of a new virus, as well as the risk of traveling during the COVID-19 virus pandemic. The financial risk factor explains $13.05 \%$ of the variance and refers to the concern that the trip will affect the financial situation, that it will not provide value for money, unforeseen costs and the concern that COVID-19 will cause higher travel costs (e.g. for food and drink). 
Table 2. Results of principal components analysis with varimax rotation

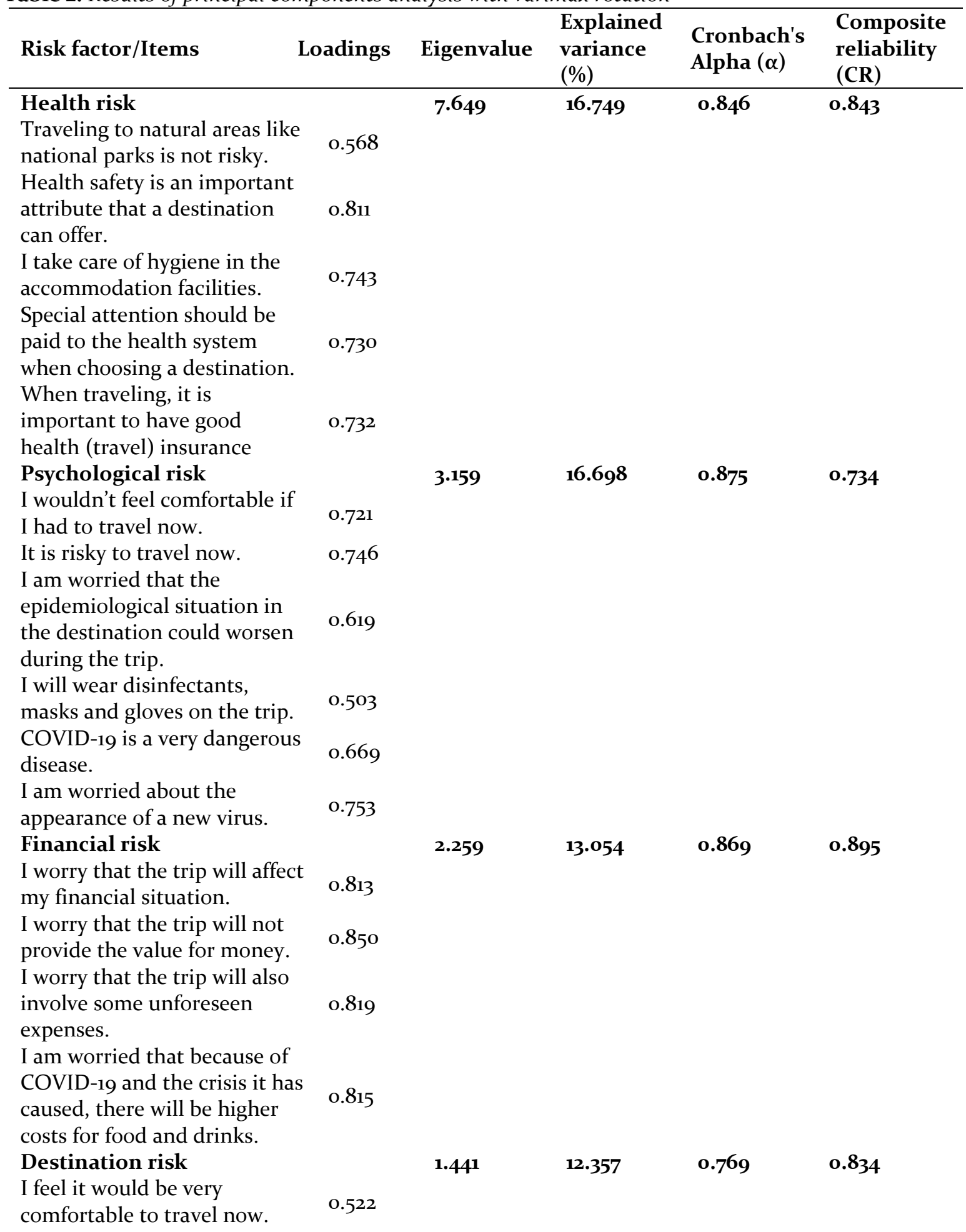


Traveling to natural areas like national park is not risky.

Visits to museums and other

tourist attractions are not

risky.

Visits to swimming pools and other water attractions are

not risky.

Traveling near the place of residence is not risky.

Travel risk

Due to COVID-19, I will avoid traveling in organized groups.

Due to COVID-19, I will use

only my own transport for the

trip.

Due to COVID-19, I will not

use air transport for travel.
0.578

0.860

0.824

0.726

$\begin{array}{llll}1.175 & 9.331 & 0.803 & 0.741\end{array}$

0.636

0.798

0.655

Note: Total explained variance $=68.18 \%$, KMO measure of sampling adequacy $=0.888$, Bartlett's test of sphericity $=4549,74, p<0.000$

The coefficient of reliability of the factor is high and amounts to $\alpha=0.86$; $C R=0.89$. The fourth factor, the destination risk, explains $12.35 \%$ of the variance, and the reliability of the factor is satisfactory and amounts to $\alpha=0.76$; $C R=0.83$. Statements within this risk are related to the risk assessment of travel to natural areas and destinations located near the place of residence, as well as visits to museums and other tourist attractions and sights. The fifth factor, the travel risk, explains the lowest percentage of variance (9.33), and its reliability coefficient indicates good reliability $(\alpha=0.83 ; C R=0.74)$ and consistency of statements in the factor. This risk is related to the way of traveling during the COVID-19 virus pandemic, i.e. the perception of the risk of traveling in organized groups and by plane, as well as the use of one's own transportation when traveling.

This study has identified five of the seven typically identified categories of perceived risk by PCA (Sharifpour et al., 2014). Research findings support the view that perceived risk is a multidimensional construct (Fuchs \& Reichel, 2006; Tsaur et al., 1997). The perceived risk factors identified in this study are consistent with those identified in the previous studies (Deng \& Ritchie, 2018; Jonas et al., 2010; Fuchs \& Reichel, 2006; Wen et al., 2005; Floyd et al., 2004).

To examine how perceived risk affects the travel intentions and destinations during the COVID-19 pandemic, two models were applied with the control of socio-demographic characteristics. In the first model, the dependent variable is the intention to travel which is a dichotomous variable coded as dummy (o-No and 1-Yes). The first model included all respondents $(\mathrm{N}=348)$. In the second model, the dependent variable is the destination of the trip, which is also a dichotomous variable coded with o-In the country and 1-Abroad. The second model included only subjects who intended to travel during the COVID-19 virus pandemic $(\mathrm{N}=265)$. In the first step, control variables were entered, and then the variables of interest, predictor variables in the second step.

The first model (table 3), where the dependent variable is the intention to travel, the model with only control variables is not statistically significant $\left(\chi_{2}(8)=5.81, p=0.67\right)$, and the model with independent 
variables is $\left(\chi_{2}(13)=66.02, p=0.00\right)$, which means that independent variables significantly contribute to the explanation of the dependent variable. The control variables explain between $1.7 \%$ (Cox and Snell $\mathrm{R}_{2}$ ) and $2.5 \%$ (Nagelkerke $\mathrm{R}_{2}$ ) of the variance of the dependent variable. The model with predictor variables explains between $\mathbf{1 7 . 3 \%}$ (Cox and Snell R2) and 25.9\% (Nagelkerke R2) of the variance of the dependent variable.

Table 3. Results of logistic regression analysis - first model

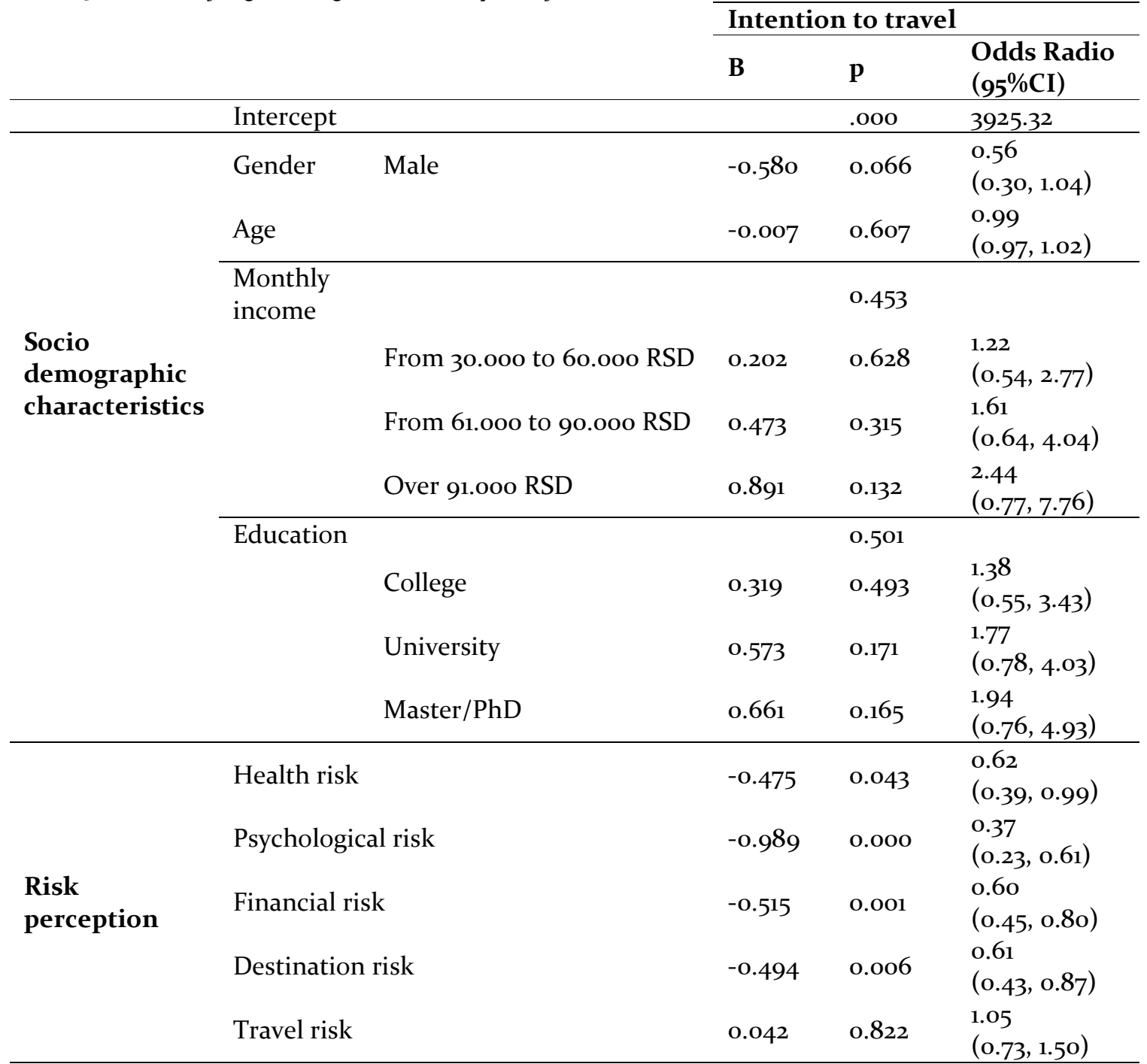

As already mentioned, the first model included all respondents $(\mathrm{N}=348)$ and the results indicate that 71.6\% of respondents plan to travel during the COVID 19 pandemic, which is in line with research that focused on examining the intention to travel during the current pandemic (Ivanova et al., 2020; Kourgiantakis et al., 2020). In the first model, when the effect of control variables is removed, the independent variables that contribute to explaining the travel intentions during the COVID-19 virus pandemic are the health risk $(\mathrm{p}=0.04)$, the psychological risk $(\mathrm{p}=\mathrm{o.00})$, the financial risk $(\mathrm{p}=\mathrm{o} .00)$, and the destination risk $(\mathrm{p}=\mathrm{o} .01)$. The health risk showed a negative impact on travel intentions, i.e. research 
findings indicate that an increase in the health risk assessment reduces the chance of traveling during the COVID-19 virus pandemic $(\mathrm{OR}=0.62 ; 95 \% \mathrm{CI}=0.39-0.99 ; \mathrm{p}=0.04)$. The results on the perception of health risk are not surprising considering the fact that the pandemic has affected the whole world and burdened the entire health system, and after six months and more than six million infected in the COVID-19 pandemic, there are still so many uncertainties about this virus. Certainly, tourist movements inside and outside Serbia will undoubtedly be accompanied by a significant dose of fear and caution. On the other hand, a study conducted among Finnish tourists who travelled to Asia during the bird flu epidemic had opposite results, and its findings revealed willingness to take health risks while traveling (Aro et al. 2009). This finding indicates that travel itself has a hedonistic function, i.e. tourists want to relax on the trip and are willing to take a higher level of risk, and that cancellation or change of plan is not such a common option, even if there are health risks (Aro et al. 2009). Also, understanding risk can reduce the risk perception, consequently affecting the willingness to behave. The findings of a recent study conducted in Bulgaria indicate changes in the behaviour of Bulgarian tourists who pay attention to the importance of hygiene, disinfection and reliability of the health system, i.e. they adopted a "new" protocol as an additional standard in the tourism industry, to minimize health risks, personal safety and safekeeping (Ivanova et al., 2020). When it comes to the psychological risk, research findings indicate that increasing psychological risk assessment reduces the chance of traveling during a pandemic ( $\mathrm{OR}=0.37 ; 95 \% \mathrm{CI}=0.23-0.61 ; \mathrm{p}=0.00)$. Due to isolation and quarantine, a large number of people were forced to spend time on the Internet and social networks, which had an impact on changing the perception of risk, from "worry" to "panic", which was directly influenced by media reports (Yu et al., 2020), panic on social media spread faster than COVID-19 infection (Depoux et al., 2020). The level of concern of individuals also plays a significant role in determining their perception of risk (Chien et al., 2017). In addition, the perception of risk was influenced by daily press conferences attended by doctors, i.e. epidemiologists, infectologists and immunologists. In this study, as already stated, health and psychological risk showed a negative impact on travel intentions, which is in line with the study of Chiu et al. (2019), which found that health and psychological risks significantly negatively affected travel intentions among the younger Malaysian population. In any case, it should be noted that the comparisons between these studies are highly questionable, given the different structure of the respondents, as well as the context of the research itself. Furthermore, research findings indicate that increasing levels of financial risk reduce the ability to travel during the COVID-19 virus pandemic $\left(\mathrm{OR}=0.60 ; 95 \% \mathrm{CI}=0.45^{-0.80} ; \mathrm{p}=0.00\right)$. This finding is in accordance with the results of similar studies in the field of tourism (Chiu et al., 2019; Li et al., 2018). Free time and free money, in addition to motivation, are the basic prerequisites for travel. During the pandemic and the state of emergency, according to the research of the SeConS group and the Friedrich Ebert Foundation (2020), 8\% of employees lost their jobs in the Republic of Serbia, so the results on the negative impact of financial risk on travel intentions during the COVID-19 virus pandemic are not surprising. The biggest hit was suffered by employees in catering and hospitality, trade (does not apply to grocery stores), arts, entertainment and recreation, communications and other service activities. When it comes to the destination risk, research findings indicate that the destination risk negatively affects the travel intentions, i.e. increasing the risk assessment of the destination reduces the chance of traveling during the COVID-19 pandemic $(\mathrm{OR}=0.61 ; 95 \% \mathrm{CI}=0.43-0.87 ; \mathrm{p}=0.01)$. It is generally known that tourists choose destinations with less risk, and destinations that they perceive as risky may become undesirable (Crompton, 1992), except that in this case it is not a specific destination. The findings of the research suggest that the respondents estimate that visits to natural areas, museums and other tourist attractions and sights pose a potential risk, which may be related to the epidemiological situation. The latest research indicates that after the end of the pandemic, tourist trends will be directed towards natural attractions with shorter trips, and that safety and cleanliness will be the main factors determining the 
choice of tourist destination (Ashikul et al., 2020; Bakar \& Rosbi, 2020; Wachyuni \& Kusumaningrum, 2020; Zhu \& Deng, 2020).

In the second model (table 4), where the dependent variable is the travel destination, the model with only control variables is statistically significant $\left(\chi_{2}(8)=39.76, p=0.00\right)$, as well as the model with independent variables $\left(\chi_{2}(13)=58.82, \mathrm{p}=0.00\right)$, which means that both the control and independent variables significantly contribute to the explanation of the dependent variable.

Table 4. Results of logistic regression analysis- second model

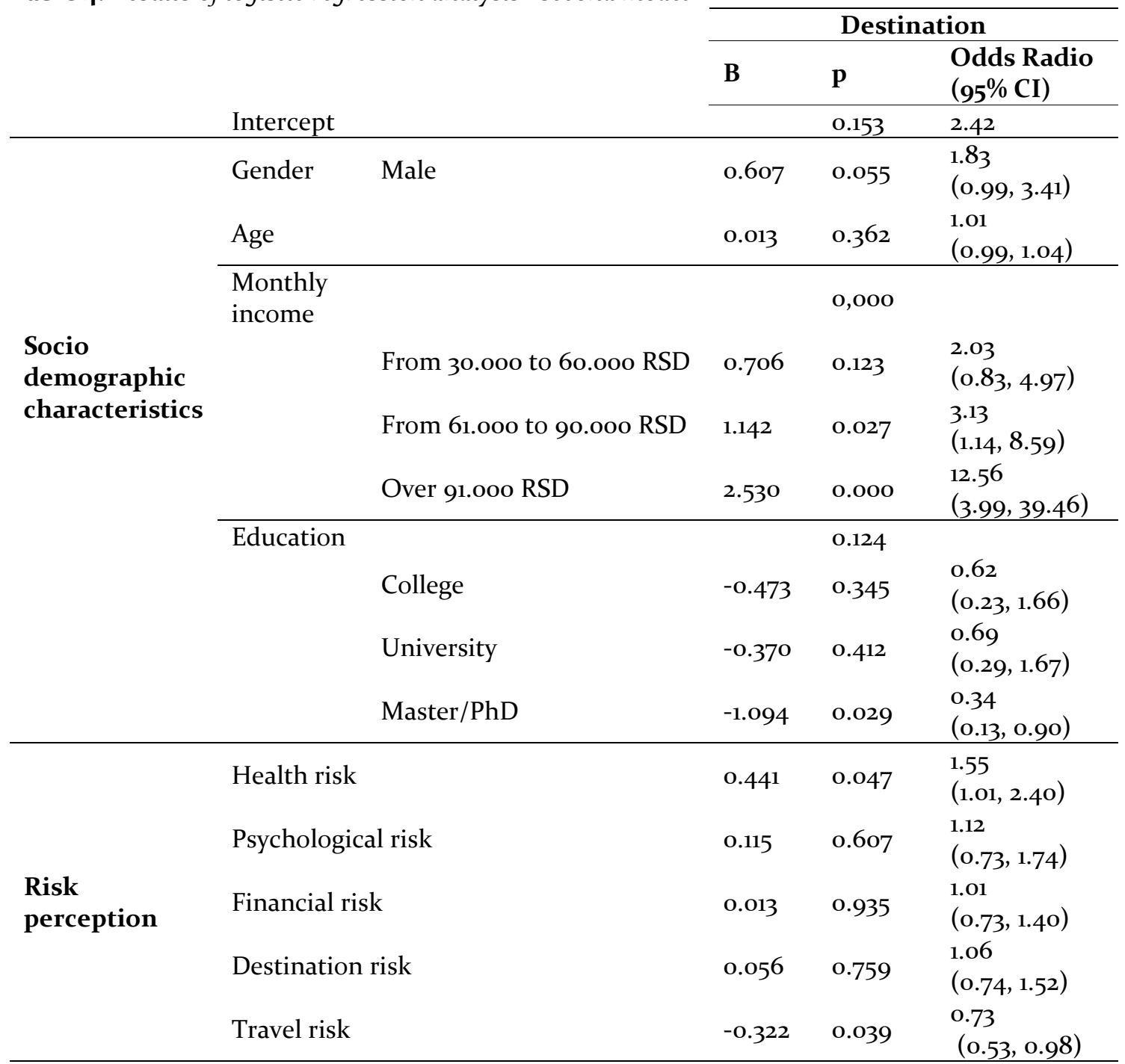

The control variables explain between 13.9\% (Cox and Snell R2) and 18.7\% (Nagelkerke R2) of the variance of the dependent variable. The model with predictor variables explains between 19.9\% (Cox and Snell R2) and 26.7\% (Nagelkerke R2) of the variance of the dependent variable. The second model included only respondents who intend to travel during the COVID-19 pandemic $(\mathrm{N}=265)$, and the survey 
results indicate that $56.6 \%$ of respondents have plans to travel in the country, while $43.4 \%$ intend on travelling abroad.

In the second model, where the dependent variable is the destination of travel, when the effect of control variables is removed, the independent variable that contributes to the explanation of travel destination during the COVID-19 virus pandemic is the travel risk $(\mathrm{p}=0.03)$, increasing the risk assessment of travel reduces the chance of traveling abroad during a pandemic $\left(\mathrm{OR}=0.73 ; 95 \% \mathrm{CI}=0.53^{-}\right.$ o.98). The increased perception of travel risk during the COVID-19 pandemic is reliable with the results of previous studies on travel during infectious disease epidemics (Wang et al., 2020; Wen at al., 2020; Neuburger \& Egger, 2020; Cahyanto et al., 2016; Lee et al., 2012; Leggat et al., 2010). This risk is related to the way of traveling during the COVID-19 virus pandemic, i.e. the perception of the traveling risk by plane and in organized groups. The plane is an ideal space for virus transmission (Baker, 2015), which implies that respondents perceive that traveling by plane increases the risk of infection. Health risk is on the verge of significance $(\mathrm{p}=0.05)$ and the findings indicate that an increase in health risk assessment increases the chance of traveling abroad during the COVID-19 virus pandemic ( $\mathrm{OR}=1.55 ; 95 \% \mathrm{CI}=1.01$ 2.40; $\mathrm{p}=0.05$ ). This finding indicates that the respondents perceive that the health risk is lower abroad, i.e. that they will travel abroad and that they are ready to take a health risk, which is in accordance with the results obtained by Aro et al. (2009) examining Finnish tourists who travelled to China during the bird flu epidemic. This finding contradicts the results of the latest studies on the travel intentions during the COVID-19 pandemic, which indicate that tourist trends are primarily focused on domestic tourism (Ivanova et al., 2020; Kourgiantakis et al., 2020). From the control variables that significantly contribute to the explanation of the dependent variable, monthly revenues were derived $(p=0.00)$. Although the variable education is not significant $(\mathrm{p}=\mathrm{o.12})$, the last category proved to be significant as a predictor Master/PhD ( $\mathrm{p}=\mathrm{0.03}$ ). Two categories of monthly income stood out as a significant predictor of travel abroad during the COVID-19 virus pandemic. Respondents who have a monthly income of 61,0oo to 90,00o RSD have a higher chance of traveling abroad ( $\mathrm{OR}=3.13 ; 95 \% \mathrm{CI}=1.14-8.59 ; \mathrm{p}=0.03$ ) compared to those who have a monthly income below $30,000 \mathrm{RSD}$. The same situation is with respondents who have a monthly income over RSD 91,00o ( $\mathrm{OR}=12.56$; 95\% CI=3.99-39.46; $\mathrm{p}=0.00)$. Based on this finding, it can be concluded that the monthly income of Serbian tourists is a significant predictor of travel abroad during the COVID-19 virus pandemic. This finding is consistent with the results of previous studies (Floyd et al., 2004; Sönmez \& Graefe, 1998b). Respondents who have a master's or PhD degree are less likely to travel abroad $(\mathrm{OR}=0.33 ; 95 \% \mathrm{CI}=0.12-0.87 ; \mathrm{p}=0.03)$ compared to respondents with high school. This finding can be related to the perceived risk that respondents with a higher level of education have.

\section{Conclusion}

The tourism industry is one of the most susceptible industries to crises and natural disasters. It is particularly vulnerable to health crises, given the fact that travel affects the spread of the epidemic. The COVID-19 pandemic is the biggest challenge of our time and it is causing enormous damage to the global tourism industry. Perception of risks and travel restrictions have caused potential tourists to move or cancel their travel plans en masse. The perception of risk has certainly been influenced by wellknown experts and epidemiologists who call to travel while the pandemic is still active or until the vaccine for COVID-19 is invented.

This study is among the first to provide a timely discussion within tourism discourse about the impact of the perceived risk on travel intentions during the COVID-19 pandemic and it deepens the understanding of the relationship between the perceived risk and the travel intentions during an epidemic outbreak. The PCA identified five categories of perceived risk that affect travel intentions during the COVID-19 pandemic, specifically: health risk, psychological risk, financial risk, destination 
risk, and travel risk. The results of logistic regression indicate that the perception of risk negatively affects travel intentions, i.e. the perception of respondents indicates a reduction in travel plans during the pandemic. Furthermore, in the first model, where the dependent variable is the travel intention, results have indicated that the health, psychological, financial, and destination risks negatively affect the travel intention during the COVID-19 virus pandemic. In the second model, where the dependent variable was the destination of the trip, the results indicate that the travel risk negatively affects the intention to travel abroad. Interestingly, in the second model, the perception of health risk indicates a positive impact on the intention to travel abroad, i.e. the results indicate that the respondents perceive that the health risk is lower abroad. From the control variables, as a significant predictor of travel abroad during the COVID-19 pandemic, the variable monthly income of the respondents stood out. The results of the research point to the conclusion that tourist movements will be mainly focused on travel within the Republic of Serbia, as well as that travel within the country and abroad will be accompanied by great caution. The results indicate the importance of health security, hygiene in accommodation facilities, a consistent health care system and health insurance. In addition, the results of this study provide insights regarding tourist behaviour during the epidemics and the pandemics in the future.

The study of tourist risk perception is the basis for understanding the attitudes and behaviour of tourists regarding risks and it provides an opportunity for destination management and tourism organizations to formulate a strategy for risk management in tourism. Accordingly, it is necessary to take appropriate measures. Firstly, in serious health crises, such as the COVID-19 pandemic, tourist destinations need to make stronger complete risk management and control, in order to successfully moderate perceived risk among potential tourists. This includes the development of communication strategies, bearing in mind the fact that information, especially found on the Internet or social networks, can have an impact on risk perception (Yu et al., 2020; Depoux et al., 2020). As a result, potential tourists should not only be provided with information on the epidemiological situation, but also information on hygiene and health safety, as well as on cancellation, refund or travel delay policies. Secondly, travel agencies must manage the travel arrangement in such a way that exposure to uncontrolled risk determinants is minimized, i.e. to a level at which it is possible to participate in tourist travel without any limitations, especially taking into account the details about high hygiene standards. Furthermore, according to the findings of this study, domestic and foreign destinations and tourist organizations can develop strategies for attracting Serbian tourists. This is especially true for domestic destinations and organizations, given the fact that tourist trips will be directed within the country. Therefore, it is important to promote domestic tourism as a short-term measure for the recovery of the domestic tourism industry on the one hand, and to point to the importance of hygiene in accommodation facilities on the other hand, as well as all other activities that will make tourists feel safe, which will reduce the perceived risk. Certainly, this study practically provides insight into the importance of justifying the identified categories of the perceived risk that affect travel intentions, especially in the short and medium term, thus enabling destination management and marketing to address current consumer trends caused by the COVID-19 pandemic.

Certain limitations of the research need to be pointed out. The main research limitation is that it focuses only on tourists in one country, i.e. Serbia. Another limitation is the way in which the travel intention during the COVID-19 virus pandemic is measured. Explicitly, the travel intention was measured as a general measure, i.e. whether tourists will travel and where tourists will travel, and therefore we should be careful regarding the generalization of the results. More precisely, the intention of the trip was not specific to a particular destination or the type of trip. Accordingly, we can conclude that the results of the study provide only a partial insight into the relationship between the perceived risk and the intention to travel during the COVID-19 pandemic. Certainly, the results of the study allow future research in this area. As one of the recommendations for future research, one could point to the 
possibility of a more comprehensive research that would include tourists from other countries and previous travel experience in the model. In addition, given the fact that the duration of the pandemic is uncertain, it would be interesting to perform the same research at certain intervals during the period of the pandemic. Certainly, it would be useful to examine the differences in the perceived risk according to the socio-demographic characteristics of the respondents.

\section{References}

Abukhalifeh, A., Faller, E. M., Ahman, A., \& Tadros S. (2018). Current issue in Tourism: Diseases Transformation as Potential Risks for Travellers. Global and Stochastic Analysis, 5(7), 841-850.

Aro, A. R., Vartti, A. M., Schreck, M., Turtiainen, P., \& Uutela, A. (2009). Willingness to take travelrelated health risks-a study among Finnish tourists in Asia during the avian influenza outbreak. International Journal of Behavioral Medicine, 16(1), 68-73. https://doi.org/10.1007/s12529oo8-9003-7

Ashikul H., Farzana, A., Mohammad, H., Ishtiaque, A., \& Abu Bakar, A. (2020). The Effect of Coronavirus (COVID-19) in the Tourism Industry in China. Asian Journal of Multidisciplinary Studies, 3 (1), 1-7.

$\mathrm{Au}$, A. K., Ramasamy, B., \& Yeung, M. C. (2005). The effects of SARS on the Hong Kong tourism industry: An empirical evaluation. Asia Pacific Journal of Tourism Research,10(1), 85-95. https://doi.org/10.1080/1094166042000330236

Bae, S. Y., \& Chang, P. J. (2020). The effect of coronavirus disease-19 (COVID-19) risk perception on behavioural intention towards 'untact' tourism in South Korea during the first wave of the pandemic (March 2020). Current Issues in Tourism, 1-19. https://doi.org/10.108o/13683500.2020.1798895

Bakar, N. A., \& Rosbi, S. (2020). Effect of Coronavirus disease (COVID-19) to tourism industry. International Journal of Advanced Engineering Research and Science, 7(4), 189-193. https://dx.doi.org/10.22161/ijaers.74.23

Baker, D. M. A. (2015). Tourism and the Health Effects of Infectious Diseases: Are There Potential Risks for Tourists? International Journal of Safety and Security in Tourism and Hospitality, 1(12), 1-17.

Bauer, R. (200o). Consumer behavior as risk taking. In M. Baker (Ed.), Marketing: Critical Perspectives on Business and Management (pp. 13-21). Routledge.

Brewer, N. T., Chapman, G. B., Gibbons, F. X., Gerrard, M., McCaul, K. D., \& Weinstein, N. D. (2007). Meta-analysis of the relationship between risk perception and health behavior: the example of vaccination. Health Psychology, 26(2), 136-145. https://psycnet.apa.org/doi/10.1037/o2786133.26 .2 .136

Brin, E. (2006). Politically-oriented tourism in Jerusalem. Tourist Studies, 6(3), $215-243$. https://doi.org/10.1177/1468797607076672

Brouder, P., Teoh, S., Salazar, N. B., Mostafanezhad, M., Pung, J. M., Lapointe, D., ... \& Clausen, H. B. (2020). Reflections and discussions: tourism matters in the new normal post COVID-19. Tourism Geographies, 1-12. https://doi.org/10.1080/14616688.2020.1770325

Burkle, F. M. Jr, (2006). Globalization and disasters: Issues of public health, state capacity and political action. Journal of International Affairs, 59(2), 231-265.

Cahaner, L., Mansfeld, Y., \& Jonas, A. (2015). Between myths and risk perception among religious tourists: the case of the Haredim. Acta Turistica, 27(1), 8-31.

Cahyanto, I., Wiblishauser, M., Pennington-Gray, L., \& Schroeder, A. (2016). The dynamics of travel avoidance: The case of Ebola in the US. Tourism Management Perspectives, 20, 195-203. https://doi.org/10.1016/j.tmp.2016.09.004

Carter, S. (1998). Tourists' and travellers' social construction of Africa and Asia as risky locations. Tourism Management, 19(4), 349-358. https://doi.org/10.1016/So261-5177(98)ooo32-6 
Chang, C.L., McAleer, M., \& Ramos, V. (2020). A Charter for Sustainable Tourism after COVID-19, Sustainability, 12(9), 3671 https://doi.org/10.3390/su12093671

Chen, H. J., Wong, S. W., Bilgihan, A., \& Okumus, F. (2020b). Capsule hotels: Offering Experiential Value or perceived as risky by tourists? An optimum stimulation level model. International Journal of Hospitality Management, 86, 102434. https://doi.org/10.1016/j.ijhm.2019.102434

Chen, H., Huang, X., \& Li, Z. (2020a). A content analysis of Chinese news coverage on COVID-19 and tourism, Current Issues in Tourism, 8(1), 1368-1376. https://doi.org/10.108o/13683500.2020.1763269

Cheron, E. J., \& Ritchie, J. B. (1982). Leisure activities and perceived risk. Journal of Leisure Research, 14(2), 139-154. https://doi.org/10.1080/00222216.1982.11969511

Chien, P. M., Sharifpour, M., Ritchie, B. W., \& Watson, B. (2017). Travelers' health risk perceptions and protective behavior: a psychological approach. Journal of Travel Research, 56(6), 744-759. https://doi.org/10.1177/2Foo47287516665479

Chinazzi, M., Davis, J. T., Ajelli, M., Gioannini, C., Litvinova, M., Merler, S., ... \& Viboud, C. (2020). The effect of travel restrictions on the spread of the 2019 novel coronavirus (COVID-19) outbreak. Science, 368(6489), 395-400. https://doi.org/10.1126/science.aba9757

Chiu, L. K., Ting, C., Alananzeh, O. A., \& Hua, K. (2019). Perceptions of risk and outbound tourism travel intentions among young working Malaysians. Dirasat, Human and Social Sciences, 46(1), 368-379.

Cooper, C. (2005). Japanese tourism and the SARS epidemic of 2003. Journal of Travel E Tourism Marketing, 19(2/3), 117-131. https://doi.org/10.1300/Jo73v19no2_10

Cossens, J., \& Gin, S. (1995). Tourism and AIDS: The perceived risk of HIV infection on destination choice. Journal of Travel E Tourism Marketing, 3(4), 1-20. https://doi.org/10.130o/Jo73vo3no4_01

Cró, S., \& Martins, A. M. (2017). Structural breaks in international tourism demand: Are they caused by crises or disasters? Tourism management, 63, 3-9. https://doi.org/10.1016/j.tourman.2017.05.009

Crompton, J. (1992). Structure of vacation destination choice sets. Annals of Tourism Research, 19(3), 420-434. https://doi.org/10.1016/o16o-7383(92)90128-C

Deng, R., \& Ritchie, B. W. (2018). International university students' travel risk perceptions: an exploratory study. Current Issues in Tourism, 21(4), 455-476. https://doi.org/10.1080/13683500.2016.1142939

Depoux, A., Martin, S., Karafillakis, E., Preet, R., Wilder-Smith, A., \& Larson, H. (2020). The pandemic of social media panic travels faster than the COVID-19 outbreak. Journal of Travel Medicine, 27(3), taaao31. https://doi.org/10.1093/jtm/taaao31

Estevão, C., \& Costa, C. (2020). Natural disaster management in tourist destinations: a systematic literature review. European Journal of Tourism Research, 25, 2502. https://ejtr.vumk.eu/index.php/about/article/view/417

Floyd, D. L., Prentice-Dunn, S., \& Rogers, R. W. (2000). A meta-analysis of research on protection motivation theory. Journal of Applied Social Psychology, 30(2), 407-429. https://doi.org/10.1111/j.1559-1816.200o.tbo2323.x

Floyd, M. F., \& Pennington-Gray, L. (2004). Profiling risk perceptions of tourists. Annals of Tourism Research, 31(4), 1051-1054. http://dx.doi.org/10.1016/j.annals.2004.03.011

Floyd, M. F., Gibson, H., Pennington-Gray, L., \& Thapa, B. (2004). The effect of risk perceptions on intentions to travel in the aftermath of September 11, 2001. Journal of Travel $\mathcal{E}$ Tourism Marketing, 15(2-3), 19-38. https://doi.org/10.1300/Jo73v15no2_02

Fuchs, G., \& Reichel, A. (2006). Tourist destination risk perception: The case of Israel. Journal of Hospitality $\mathcal{E}$ Leisure Marketing, 14(2), 83-108. https://doi.org/10.1300/J150v14no2_o6

Gibson, H., \& Yiannakis, A. (2002). Tourist roles: Needs and the lifecourse. Annals of tourism research, 29(2), 358-383. https://doi.org/10.1016/So16o-7383(01)ooo37-8 
Gössling, S., Scott, D., \& Hall, M. (2020). Pandemics, tourism and global change: a rapid assessment of COVID-19. Journal of $\quad$ Sustainable $\quad$ Tourism, $1747-1764$. https://doi.org/10.108o/o9669582.2020.1758708

Grout, A. (2015). 'To Spray or Not to Spray': Developing a Tourism-Linked Research Agenda for Aircraft Disinsection. European Journal of Tourism Research, 10, 35-50.

Haddock, C. (1993). Managing risks in outdoor activities. New Zealand Mountain Safety Council.

Henthorne, T. L., George, B. P., \& Smith, W. C. (2013). Risk perception and buying behavior: An examination of some relationships in the context of cruise tourism in Jamaica. International Journal of Hospitality $\mathcal{E}$ Tourism Administration, 14(1), 66-86. https://doi.org/10.108o/15256480.2013.753808

Hoque, A., Shikha, F. A., Hasanat, M. W., Arif, I., \& Hamid, A. B. A. (2020). The effect of Coronavirus (COVID-19) in the tourism industry in China. Asian Journal of Multidisciplinary Studies, 3(1), 5258.

Hwang, J., \& Choe, J. Y. (2020). How to enhance the image of edible insect restaurants: Focusing on perceived risk theory. International Journal of Hospitality Management, 87, 102464. https://doi.org/10.1016/j.ijhm.2020.102464

Ivanova, M., Ivanov, I. K., \& Ivanov, S. (2020). Travel behaviour after the pandemic: the case of Bulgaria. Anatolia. https://doi.org/10.108o/13032917.2020.1818267

Jacoby, J., \& Kaplan, L. (1972). The components of risk perception. In Proceedings of the 3rd annual conference (pp. 382-393). Association for Consumer Research Champaign.

Jamal, T., \& Budke, C. (2020). Tourism in a world with pandemics: local-global responsibility and action. Journal of Tourism Futures, 6(2), 181-188 https://doi.org/10.1108/JTF-02-2020-0014

Jonas, A., Mansfeld, Y., Paz, S., \& Potasman, I. (2010). Determinants of health risk perception among low-risk-taking tourists traveling to developing countries. Journal of Travel Research, 50(1), 87-99. https://doi.org/10.1177/o047287509355323

Kourgiantakis, M., Apostolakis, A., \& Dimou, I. (2020). COVID-19 and holiday intentions: the case of Crete, Greece. Anatolia. https://doi.org/10.1080/13032917.2020.1781221

Kozak, M. (2001). Repeaters' behavior at two distinct destinations. Annals of tourism research, 28(3), 784-807. https://doi.org/10.1016/So16o-7383(oo)ooo78-5

Kozak, M., Crotts, J. C., \& Law, R. (2007). The impact of the perception of risk on international travellers. International Journal of Tourism Research, 9(4), 233-242. https://doi.org/10.1002/jtr.607

Kuo, H. I., Chang, C. L., Huang, B. W., Chen, C. C., \& McAleer, M. (20o9). Estimating the impact of avian flu on international tourism demand using panel data. Tourism Economics, 15(3), 501-511. https://doi.org/10.5367\%2Foooooooo9789036611

Le, T. H., \& Arcodia, C. (2018). Risk perceptions on cruise ships among young people: Concepts, approaches and directions. International Journal of Hospitality Management, 69, 102-112. https://doi.org/10.1016/j.ijhm.2017.09.016

Lee, C. K., Song, H. J., Bendle, L. J., Kim, M. J., \& Han, H. (2012). The impact of non-pharmaceutical interventions for $2009 \mathrm{HiN}_{1}$ influenza on travel intentions: A model of goal-directed behavior. Tourism Management, 33(1), 89-99. https://doi.org/10.1016/j.tourman.2011.02.006

Leggat, P. A., Brown, L. H., Aitken, P., \& Speare, R. (2010). Level of concern and precaution taking among Australians regarding travel during pandemic $\left(\mathrm{H}_{1} \mathrm{~N}_{1}\right)$ 2009: results from the 2009 Queensland Social Survey. Journal of Travel Medicine,17(5), 291-295. https://doi.org/10.1111/j.17088305.2010.00445.X

Lepp, A., \& Gibson, H. (2003). Tourist roles, perceived risk and international tourism. Annals of tourism research, 30(3), 6o6-624. https://doi.org/10.1016/So16o-7383(03)0o024-o 
Lepp, A., \& Gibson, H. (2008). Sensation seeking and tourism: Tourist role, perception of risk and destination choice. Tourism Management, 29(4),

740-750. https://doi.org/10.1016/j.tourman.2007.08.002

Li, Y., Li, S., Ma, B., \& Liu, Y. (2018). Study on Influencing Factors of Travel Intention after Disaster: a Case Study of the 8 August Jiuzhaigou Earthquake. In 8th International Conference on Education, Management, Information and Management Society (EMIM 2018). Atlantis Press.

Ma, C., Rogers, J., \& Zhou, S. (2020). Global Economic and Financial Effects of 21st Century Pandemics and Epidemics. http://dx.doi.org/10.2139/ssrn.3565646 (Accessed on 05.06.2020.).

MacLaurin, T. L. (2004). The importance of food safety in travel planning and destination selection. Journal of Travel $\mathcal{E} \quad$ Tourism $\quad$ Marketing, 15(4), 233-257. https://doi.org/10.1300/Jo73v15no4_02

Mair, J., Ritchie, B.W. and Walters, G. (2016). Towards a research agenda for post-disaster and postcrisis recovery strategies for tourist destinations: a narrative review. Current Issues in Tourism, 19(1), 126. https://doi.org/10.1080/13683500.2014.932758

Matiza, T. (2020). Post-COVID-19 crisis travel behaviour: towards mitigating the effects of perceived risk. Journal of Tourism Futures. https://doi.org/10.1108/JTF-04-2020-0063

Mattila, A. (2001). The impact of product category risk on service satisfaction evaluations. International Journal of Hospitality Management, 20(1), 29-43. https://doi.org/10.1016/So278-4319(oo)ooo42-6

McKercher, B., \& Chon, K. (2004). The over-reaction to SARS and the collapse of Asian tourism. Annals of Tourism Research, 31(3), 716-719. https://doi.org/10.1016/j.annals.2003.11.002

McKercher, B., \& Hui, E. L. (2004). Terrorism, economic uncertainty and outbound travel from Hong Kong. Journal of Travel $\mathcal{E}$ Tourism Marketing, 15(2-3), 99-115. https://doi.org/10.1300/Jo73v15no2_o6

Milićević, S., \& Ervaćanin, V. (2016). Uticaj kriza na razvoj turizma u svetu. Turističko poslovanje, 18(1), 51-63. https://doi.org/10.5937/TurPos1618051M

Mitchell, V. W., \& Vassos, V. (1998). Perceived risk and risk reduction in holiday purchases: A crosscultural and gender analysis. Journal of Euromarketing, 6(3), 47-79. https://doi.org/10.130o/Jo37vo6no3_03

Nepal, S. K. (2020). Travel and tourism after COVID-19 - business as usual or opportunity to reset? Tourism Geographies, 1470-1340. https://doi.org/10.108o/14616688.2020.1760926

Neuburger, L., \& Egger, R. (2020). Travel risk perception and travel behaviour during the COVID-19 pandemic 2020: a case study of the DACH region. Current Issues in Tourism. https://doi.org/10.1080/13683500.2020.1803807

Pearson, R. H., \& Mundform, D. J. (2010). Recommended sample size for conducting exploratory factor analysis on dichotomous data. Journal of Modern Applied Statistical Methods, 9(2), 359-368. https://doi.org/10.22237/jmasm/1288584240

Pennington-Gray, L., \& Schroeder, A. (2013). International tourist's perceptions of safety \& security: the role of social media. Matkailututkimus, 9(1), 7-20.

Pizam, A., Jeong, G., Reichel, A., Van Boemmel, H., Lusson, J., Steynberg, L., State-Costache, O., Volo, S., Kroesbacher, C., Hucerova, J., \& Montmany, N. (2004). The relationship between risktaking, sensation-seeking, and the tourist behavior of young adults: A cross-cultural study. Journal of Travel Research, 42(3), 251-26o. https://doi.org/10.1177\%2Foo47287503258837

Qi, C. X., Gibson, H. J., \& Zhang, J. J. (2009). Perceptions of risk and travel intentions: The case of China and the Beijing Olympic Games. Journal of Sport $\mathcal{E}$ Tourism,14(1), $43-67$. https://doi.org/10.108o/14775080902847439

Quintal, V. A., Lee, J. A., \& Soutar, G. N. (2010). Tourists' information search: the differential impact of risk and uncertainty avoidance. International Journal of Tourism Research, 12(4), 321-333. https://doi.org/10.1002/jtr.753 
Reisinger, Y., \& Mavondo, F. (2005). Travel anxiety and intentions to travel internationally: Implications of travel risk perception. Journal of Travel Research,43(3), 212-225. https://doi.org/10.1177\%2Foo47287504272017

Reisinger, Y., \& Mavondo, F. (2006). Cultural differences in travel risk perception. Journal of Travel E Tourism Marketing, 20(1), 13-31. https://doi.org/10.1300/Jo73v20no1_02

Richter, L. K. (2003). International tourism and its global public health consequences. Journal of Travel Research, 41(4), 340-347. https://doi.org/10.1177\%2Fo047287503041004002

Rittichainuwat, B. N., \& Chakraborty, G. (2009). Perceived travel risks regarding terrorism and disease: The case of Thailand. Tourism Management, 30(3), 410-418. https://doi.org/10.1016/j.tourman.2008.08.001

Roehl, W. S., \& Fesenmaier, D. R. (1992). Risk perceptions and pleasure travel: An exploratory analysis. Journal of Travel Research, 30(4), 17-26. https://doi.org/10.1177\%2Fo04728759203000403

Roselius, T. (1971). Consumer rankings of risk reduction methods. Journal of Marketing, 35(1), 56-61. https://doi.org/10.1177\%2Foo2224297103500110

Schusterschitz, C., Schütz, H., \& Wiedemann, P. M. (2010). Looking for a safe haven after fancy thrills: a psychometric analysis of risk perception in alpine tourist destinations. Journal of Risk Research, 13(3), 379-398. https://doi.org/10.108o/13669870903134949

Seabra, C., Abrantes, J. L., \& Kastenholz, E. (2014). The influence of terrorism risk perception on purchase involvement and safety concern of international travellers. Journal of Marketing Management, 30(9-10), 874-903. https://doi.org/10.1080/0267257X.2014.934904

Seabra, C., Dolnicar, S., Abrantes, J. L., \& Kastenholz, E. (2013). Heterogeneity in risk and safety perceptions of international tourists. Tourism Management, 36, 502-510. https://doi.org/10.1016/j.tourman.2012.09.008

SeConS development initiative group and Friedrich-Ebert-Stiftung (2020). COVID-19 i zaposlenost u Srbiji: uticaj pandemije i mera za njeno sprečavanje na zaposlenost i uslove rada. SeConS development initiative group and Friedrich-Ebert-Stiftung. https://www.secons.net/files/publications/113-publication.pdf (Accessed on 07.06.2020.).

Seddighi, H. R., Nuttall, M. W., \& Theocharous, A. L. (2001). Does cultural background of tourists influence the destination choice? An empirical study with special reference to political instability. Tourism mManagement, 22(2), 181-191. https://doi.org/10.1016/So261-5177(oo)ooo46-7

Sharifpour, M., Walters, G., \& Ritchie, B. W. (2014). Risk perception, prior knowledge, and willingness to travel: Investigating the Australian tourist market's risk perceptions towards the Middle East. Journal of Vacation Marketing, 2o(2), 111-123. https://doi.org/10.1177\%2F1356766713502486

Sönmez, S. F., \& Graefe, A. R. (1998a). Determining future travel behavior from past travel experience and perceptions of risk and safety. Journal of Travel Research,37(2), 171-177. https://doi.org/10.1177\%2Fo04728759803700209

Sönmez, S. F., \& Graefe, A. R. (1998b). Influence of terrorism risk on foreign tourism decisions. Annals of Ttourism Research, 25(1), 112-144. https://doi.org/10.1016/So16o-7383(97)00072-8

Statistical Office of the Republic of Serbia. (2020). Statistical release: Catering and tourism statistics Tourist turnover August 2020 (Number 264 - Year LXX, 30.09.2020.). https://publikacije.stat.gov.rs/G2020/PdfE/G20201264.pdf

Stone, R. N., \& Grønhaug, K. (1993). Perceived risk: Further considerations for the marketing discipline. European Journal of Marketing, 27(3), 39-50. https://doi.org/10.1108/03090569310026637

Sumner, A., Hoy, C. \& Ortiz-Juarez, E. (2020) Estimates of the impact of COVID-19 on global poverty. WIDER Working Paper 2020/43. UNU-WIDER. https://doi.org/10.35188/UNU-WIDER/2020/80o9

Tabachnick, B. G., \& Fidell, L. S. (2019). Using multivariate statistics (7th edition). Pearson Education. 
Tsaur, S. H., Tzeng, G. H., \& Wang, K. C. (1997). Evaluating tourist risks from fuzzy perspectives. Annals of Tourism Research, 24(4), 796-812. https://doi.org/10.1016/So16o-7383(97)0o059-5

Uriely, N., Maoz, D., \& Reichel, A. (2007). Rationalising terror-related risks: The case of Israeli tourists in Sinai. International Journal of Tourism Research, 9(1), 1-8. https://doi.org/10.1002/jtr.587

Wachyuni, S. S., \& Kusumaningrum, D. A. (2020). The Effect of COVID-19 Pandemic: How are the Future Tourist Behavior? Journal of Education, Society and Behavioural Science, 33(4) 67-76. https://doi.org/10.9734/jesbs/2020/v33i430219

Wang, F., Xue, T., Wang, T., \& Wu, B. (2020). The Mechanism of Tourism Risk Perception in Severe Epidemic-The Antecedent Effect of Place Image Depicted in Anti-Epidemic Music Videos and the Moderating Effect of Visiting History. Sustainability, 12(13), 5454. https://doi.org/10.339o/su12135454

Wen, J., Kozak, M., Yang, S., \& Liu, F. (2020). COVID-19: potential effects on Chinese citizens' lifestyle and travel. Tourism Review. https://doi.org/10.1108/TR-03-2020-0110

Wen, Z., Huimin, G., \& Kavanaugh, R. R. (2005). The impacts of SARS on the consumer behaviour of Chinese domestic tourists. Current Issues in Tourism, 8(1), 22-38.

Wilks, J., Pendergast, D., \& Leggat, P. (Eds.). (2006). Tourism in turbulent times. Routledge.

World Economic Forum. (2020). This is how coronavirus could affect the travel and tourism industry. World Economic Forum. https://www.weforum.org/agenda/2020/o3/world-travel-coronaviruscovid19-jobs-pandemic-tourism-aviation/ (Accessed on 01.06.2020.).

World Health Organization. (2012). International travel and health. World Health Organization. https://www.who.int/publications-detail/9789241580472 (Accessed on 01.06.2020.).

World Health Organization. (2020). Coronavirus disease (COVID-19) pandemic. World Health Organization.https://www.who.int/emergencies/diseases/novel-coronavirus-2019 (Accessed on 19.10.2020.).

World Tourism Cities Federation (WTCF) and Tourism Research Center, Chinese Academy of Social Sciences (TRC-CASS) (2020), The Report on World Tourism Economy Trends 2020 https://en.wtcf.org.cn/special/2020/0113/500o.html (Accessed on 04.06.2020.).

World Tourism Organization. (2020). Impact assessment of the COVID-19 outbreak on international tourism. World Tourism Organization. https://www.unwto.org/impact-assessment-of-the-covid19-outbreak-on-international-tourism (Accessed on 03.06.2020.).

Yang, C. L., \& Nair, V. (2014). Risk Perception Study in Tourism: Are we Really Measuring Perceived Risk? Procedia-Social and Behavioral $\quad$ Sciences, 144, 322-327. https://doi.org/10.1016/j.sbspro.2014.07.302

Yang, Y., Zhang, H., \& Chen, X. (2020). Coronavirus pandemic and tourism: Dynamic stochastic general equilibrium modeling of infectious disease outbreak. Annals of Tourism Research, 83, 102913 https://doi.org/10.1016/j.annals.2020.102913

Yu, M., Li, Z., Yu, Z., He, J., \& Zhou, J. (2020). Communication related health crisis on social media: a case of COVID-19 outbreak. Current Issues in Tourism, 1-7. https://doi.org/10.1080/13683500.2020.1752632

Zeithaml, V. A., Berry, L. L., \& Parasuraman, A. (1996). The behavioral consequences of service quality. Journal of Marketing, 6o(2), 31-46. https://doi.org/10.1177/002224299606000203

Zenker, S., \& Kock, F. (2020). The coronavirus pandemic-A critical discussion of a tourism research agenda. Tourism Management, 81, 104164. https://doi.org/10.1016/j.tourman.2020.104164

Zhu, H., \& Deng, F. (2020). How to Influence Rural Tourism Intention by Risk Knowledge during COVID-19 Containment in China: Mediating Role of Risk Perception and Attitude. International Journal of Environmental Research and Public Health, 17(10), 3514. https://doi.org/10.339o/ijerphi7103514 
Received: 29/06/2020

Accepted: 05/11/2020

Coordinating editor: Stanislav Ivanov

Appendix 1 Measurement statements of perceived risk

\begin{tabular}{|c|c|c|}
\hline Statements & Original/Modified & Sources \\
\hline Traveling to natural areas like national parks is not risky. & Original & Floyd et al. (2004) \\
\hline Health safety is an important attribute that a destination can offer. & Modified & Floyd et al. (2004) \\
\hline I take care of hygiene in the accommodation facilities. & Modified & Wen et al. (2005) \\
\hline $\begin{array}{l}\text { Special attention should be paid to the health system when choosing } \\
\text { a destination. }\end{array}$ & Modified & Floyd et al. (2004) \\
\hline When traveling, it is important to have good health (travel) insurance & & Jonas et al. (2010) \\
\hline I wouldn't feel comfortable if I had to travel now. & Original & Floyd et al. (2004) \\
\hline It is risky to travel now. & Original & Floyd et al. (2004) \\
\hline $\begin{array}{l}\text { I am worried that the epidemiological situation in the destination } \\
\text { could worsen during the trip. }\end{array}$ & Original & Researchers \\
\hline I will wear disinfectants, masks and gloves on the trip. & Original & Researchers \\
\hline COVID-19 is a very dangerous disease. & Original & Researchers \\
\hline I am worried about the appearance of a new virus. & Original & Researchers \\
\hline I worry that the trip will affect my financial situation. & Original & Fuchs \& Reichel (2006) \\
\hline I worry that the trip will not provide the value for money. & Original & Fuchs \& Reichel (2006) \\
\hline I worry that the trip will also involve some unforeseen expenses. & Original & Fuchs \& Reichel (2006) \\
\hline $\begin{array}{l}\text { I am worried that because of COVID-19 and the crisis it has caused, } \\
\text { there will be higher costs for food and drinks. }\end{array}$ & Modified & Deng \&Ritchie (2018) \\
\hline $\begin{array}{l}\text { I feel it would be very comfortable to travel now. } \\
\text { Traveling to natural areas like national park is not risky. }\end{array}$ & Original & Floyd et al. (2004) \\
\hline Visits to museums and other tourist attractions are not risky. & Original & Floyd et al. (2004) \\
\hline $\begin{array}{l}\text { Visits to swimming pools and other water attractions are not risky. } \\
\text { Traveling near the place of residence is not risky. }\end{array}$ & Modified & Floyd et al. (2004) \\
\hline Due to COVID-19, I will avoid traveling in organized groups. & Modified & Wen et al. (2005) \\
\hline Due to COVID-19, I will use only my own transport for the trip. & Modified & Wen et al. (2005) \\
\hline Due to COVID-19, I will not use air transport for travel. & Modified & Wen et al. (2005) \\
\hline
\end{tabular}

